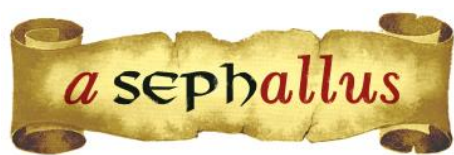

Revista aSEPHallus de Orientação Lacaniana

Núcleo Sephora de Pesquisa sobre o Moderno e o Contemporâneo

ISSN $1809-709 \mathrm{X}$

\title{
A anatomia é o destino: a psicanálise e o sintoma transexual
}

\section{Maria Cristina da Cunha Antunes}

Psicanalista

Doutorado em Teoria Psicanalítica / UFRJ (Rio de Janeiro, Brasil) Coordenadora do grupo de pesquisa sobre transtornos alimentares e obesidade mórbida do ISEPOL (Rio de

Membro do Instituto Sephora de Ensino e Pesquisa de Orientação Lacaniana / ISEPOL (Rio de Janeiro, Brasil)

E-mail: crisantunes@superig.com.br

Resumo: 0 artigo distingue a clínica do transexual e o discurso da atualidade sobre o transexualismo. Essa solução parece ter se tornado o paradigma da sexualidade na contemporaneidade. O próprio sexo se torna um direito e isso implica em admitir que a escolha do sexo é livre. Por ser presidida pela linguagem, a sexuação nada deveria ao corpo anatômico. Do ponto de vista psicanalítico, o simbólico pode ser transmitido sem estar encarnado? Sabemos que tudo o que diz respeito à experiência humana está aparelhado sob a forma de um discurso. O corpo também. Aliviado do constrangimento fálico, que diz respeito ao discurso do mestre (o Édipo, em Freud), o corpo está livre? Sabemos que não. Em que discurso ele é capturado? O que nós, psicanalistas, temos a dizer a respeito dessa nova ilusão?

Palavras-chave: psicanálise; transexual; transexualismo; sexuação; falo; corpo.

\section{L'anatomie est le destin: la psychanalyse et le symptôme transsexuel}

Résumé: Je propose une distinction entre une clinique du transsexuel et le discours de nos jours à propos du transsexualisme. Cette solution semble avoir changé le paradigme de la sexualité dans la contemporanéité. Le sexe lui-même devient un droit, ce qu'implique d'admettre que le choix du sexe est libre. Pour la raison qu'il est organisé par la langue, la sexuation ne doit rien au corps anatomique. Du point de vue psychanalytique, peut le symbolique être transmis sans être incarné? Nous savons que tout ce qui concerne l'expérience humaine s'appareille sous un discours. Le corps aussi. Celui-ci, libéré de la contrainte phallique à l'égard du discours du maître (I'CFdipe, chez Freud), est-il libre? Nous savons qu'il n'en est pas. Dans quel discours, est-il figé? Qu'estce que nous, les psychanalystes, pouvons dire de cette nouvelle illusion?

Mots-Clés: psychanalyse; transsexuel; transsexualisme; sexuation; phallus; corps.

The anatomy is destiny: psychoanalysis and the transsexual symptom

Abstract: I propose a distinction between a transsexual's clinic and today's discourse about transsexualism. This solution seems to have become the paradigm of sexuality in contemporary times. Sex itself becomes a right and this implies admitting that the sexual choice is a free one. Due to it being presided over by language, sexuation would owe nothing to the anatomical body. According to the psychoanalytical point of view, can the symbolic be transmitted without being incarnated? We know that everything that relates to human experience is trapped in discourse. So is the body. Can the latter, once freed of phallic constraint, which concerns the master's discourse (the Oedipus, in Freud), be said to be free? We know it can't. In what discourse is it caught? What do we, psychoanalysts, have to say about this new illusion?

Keywords: psychoanalysis; transsexual; transsexualism; sexuation; phallus; body. 


\title{
A anatomia é o destino: a psicanálise e o sintoma transexual
}

\author{
Maria Cristina da Cunha Antunes
}

\section{Introdução}

A provocação é intencional. Retomo a frase freudiana (1912) - "a anatomia é o destino" para indagar o que a psicanálise tem a dizer a respeito do sintoma transexual. Como entender essa afirmação de Freud em relação à sexuação dos sujeitos? Aliás, nos dias de hoje, a posição freudiana ainda faz algum sentido, para os psicanalistas, do ponto de vista teórico e clínico?

À primeira vista, o fenômeno transexual parece interrogar radicalmente a anatomia e a sua relação com a sexualidade. Segundo Castel (2001), o fenômeno transexual "é um indicador muito seguro das modificações históricas da percepção científica, mas também cultural e política da identidade sexual no século XX" (Castel, 2001, p. 77). Para os fins deste trabalho, proponho uma distinção entre a clínica do transexual e o discurso sobre o transexualismo que promove o fenômeno transexual. Esse discurso se constitui a partir dos formadores de opinião a respeito do tema do transexualismo, ou seja, médicos (psiquiatras, endócrinos, cirurgiões), psicanalistas e psicólogos.

Vou me apoiar nas reflexões de Castel para recortar a questão que pretendo desenvolver. A figura do transexualismo não é nova. Pensada como uma síndrome, foi individualizada por Benjamin (1885-1886 apud Castel, 2001). O termo transexual é utilizado pela primeira vez por Hirschfeld em 1910 e passa a ser estudado, a partir daí, no campo da sexologia e da psiquiatria. Para Castel (2001), a apresentação contemporânea do transexualismo entrelaça os seguintes campos:

- Da sociologia e da psicologia, com o surgimento da noção de gênero e a disjunção entre sexo e gênero;

- Da psiquiatria, com a definição no DSM-IV não mais sob o título de transexualismo, mas como distúrbio de identidade de gênero;

- Da cirurgia plástica, com a criação de novas técnicas capazes de satisfazer as demandas de adequação do corpo anatômico ao gênero;

- Da endocrinologia, com tratamentos hormonais que possibilitam a transformação da aparência na direção do gênero requerido.

Ainda segundo Castel (2001), a partir dos anos 1970, vem à luz a reivindicação libertária de uma despatologização radical do transexualismo e a ideia de que a identidade sexual é em si um preconceito e limita a liberdade individual. O transexualismo é descrito como neuroendócrino, por oposição a uma psicogênese. Essa teoria biológica convive bem com as teorias culturais sobre o gênero que também se opõem à ideia de um distúrbio psicogênico. Parece haver um novo gosto na cultura contemporânea que, em nome da liberdade e dos direitos do indivíduo, rejeita a diferença sexual. A minha proposta é apresentar uma investigação desse fenômeno - o aparente apagamento da diferença sexual na cultura - a partir de textos psicanalíticos que tratam do tema do transexualismo. $\mathrm{O}$ fio condutor desse trabalho gira em torno de duas perguntas: a diferença sexual 
- que se sustenta no conceito de falo - é uma noção fundamental para a psicanálise? Podemos, devemos, como analistas, abrir mão dessa noção e navegar conforme os novos ventos da contemporaneidade? Delinear essas questões envolve atravessarmos, necessariamente, a clínica psicanalítica do sintoma transexual.

\section{A clínica do sintoma transexual:}

\section{1 - O encontro do transexual com um analista:}

De modo geral, a clínica do transexual se passa no campo da psicanálise aplicada, já que são pessoas que não apresentam demanda de análise, ou seja, não procuram espontaneamente um analista. $O$ trabalho psicanalítico diz respeito à avaliação e ao acompanhamento de pacientes que querem se submeter à cirurgia de redesignação sexual. O psicanalista, portanto, faz parte de uma equipe multidisciplinar que trata desses pacientes.

A definição de transexualismo utilizada pelas equipes é a do DSM-IV que, em 1994, estabelece a experiência transexual como um distúrbio de identidade de gênero, isto é, uma disforia de gênero. Fenomenologicamente, os portadores desse transtorno apresentam três características básicas:

- São pessoas habitadas por uma convicção inabalável de que o seu sexo não é o seu;

- São compelidas por um desejo enérgico a uma operação de mudança de sexo para corrigir "um erro da natureza";

- Querem ser consideradas e legitimadas socialmente como pertencentes ao campo do sexo ao qual subjetivamente se sentem pertencer.

No Brasil, o Conselho Federal de Medicina exige um acompanhamento (pré e pós cirúrgico) desses pacientes. A recomendação desse procedimento é para que não existam dúvidas, na equipe, quanto aos resultados. O paciente deve estar preparado para a irreversibilidade do ato cirúrgico (no caso de homens, por exemplo, a retirada do pênis e dos testículos e a criação, artificialmente, de uma vagina forjada na região).

Do ponto de vista da equipe, o paciente é encaminhado ao psicanalista para uma avaliação que contemple a verificação do risco de arrependimento por parte do paciente após a cirurgia. Como medir esse risco? Um critério utilizado nas avaliações é identificar se o paciente tem prazer sexual com o órgão. Se for esse o caso, o paciente não é indicado para a cirurgia. Os casos indicados para o procedimento cirúrgico são aqueles em que o paciente não tem prazer sexual com o órgão, ou, até mesmo, tem um sentimento de repulsa em relação ao pênis. Para um psicanalista, a ausência de prazer sexual e a ojeriza ao órgão sexual não são uma configuração preocupante, grave do ponto de vista subjetivo? Além do arrependimento, que outros riscos podem estar em jogo para estes sujeitos?

\section{2 - Os psicanalistas e os transexuais: do que falam?}


Vou me servir de dois textos psicanalíticos brasileiros: Caldas (2012) e Elias (2008). A escolha se deu em função de que ambos mostram vinhetas clínicas do trabalho com os pacientes transexuais. Elias (2008) comenta que, em alguns casos, o surgimento de uma identidade transexual seria devido à formação da moral e ao sentimento de culpa em função da recusa da homossexualidade. Em alguns fragmentos clínicos apresentados, aparece na história desses sujeitos uma experiência homossexual precoce (na infância ou na adolescência) e uma enérgica reação por parte deles: "Não sou homossexual!". Em alguns, o enunciado se completa: "Então, sou uma mulher..." (Elias, 2008, p. 9).

A cisão psíquica e a busca pela alteração no corpo são explicadas pela autora como uma tentativa dos sujeitos de responder aos impasses subjetivos criados pelo mal-estar de uma cultura onde só cabe ser homem ou mulher e, assim, produzir laço social (Elias, 2008, p. 7). A autora se pergunta se essas pessoas demandariam essas modificações no corpo por não estarem de acordo com a Lei (ordem heterossexual). Elas vivem um tormento moral, tormento que ela reputa ser consequência do constrangimento e do preconceito sociais.

A hipótese de que os transexuais almejam a mais completa liberdade em relação à escolha do sexo, livre dos constrangimentos da chamada ordem heterossexual, vai na contramão dos enunciados dos pacientes nas vinhetas clínicas. Assim, numa vinheta, aparecem os seguintes enunciados de um candidato à cirurgia. Parasitado por fantasias incestuosas e homossexuais a partir da adolescência, ele diz: " Mais do que ser uma mulher, o que almejava era não parecer homem". 0 que importava, neste caso, era a retirada do pênis e dos testículos que acusavam a sua masculinidade. Segundo Elias, reagindo à posição homossexual, o paciente dizia: "Homem é homem, mulher é mulher, não existe meio termo!" (Elias, 2008, p. 8). Para a autora, este paciente, ao optar se inserir na cultura, vê no discurso médico a possibilidade de corrigir o equívoco produzido pela natureza. Não parece evidente, nesta vinheta, que o paciente precisa, desesperadamente, parecer incluído na ordem heterossexual (norma fálica) a qual ele nomeia, sem qualquer meio termo, "homem é homem, mulher é mulher"? O paciente não se parece com alguém que se situa para além da norma fálica, que pleiteia a liberdade de escolher o seu sexo e se sente livre para isso. Ao contrário, ele procura uma solução que pareça inclui-lo na norma fálica.

Outro paciente comenta o sentimento de estranheza com o próprio corpo na adolescência e um mal-estar associado ao fato de ser homem (Elias, 2008). Ele supunha que a raiz da sua decisão de mudar de sexo ligava-se ao desejo por um primo com quem manteve a primeira relação sexual aos dez anos e por quem se apaixonou. Ao identificar esse gozo como homossexual, pensou que ele próprio "deveria ser uma mulher porque achava absurdo um homem desejando outro homem. Era nojento..." (Elias, 2008, p. 9).

Em outro relato, um paciente revela o amor impossível por um amigo que pretendia tornarse padre. A intenção deste paciente era submeter-se à cirurgia para tornar-se freira, seguindo o caminho iniciado por sua mãe, que abandonou o hábito para casar-se com seu pai. Nesse caso, 
também aparecia o argumento: "Não sou homossexual porque desejo um homem sentindo-me mulher" (Elias, 2008, p. 10). Este paciente dizia sentir "náusea só de pensar" que seria homossexual e busca a saída para tornar-se heterossexual. Em relação à cirurgia, a lógica desse sujeito era a de que a vagina era necessária, pois "não há amor que não se concretize na relação sexual e não há como esconder a verdade" (Elias, 2008, p. 10). Para Elias (2008), a verdade do sexo desse paciente era ser feminino, sendo a construção de uma vagina a prova maior dessa convicção, enquanto inserida em uma cultura que assim o orienta. Entretanto, segundo a autora, a aspiração desse paciente encontrava-se na realização de um amor pleno pelo homem em que desejo e gozo estivessem excluídos.

A realização de um amor sem sexo é a hipótese explorada por Caldas (2012) no trabalho com transexuais-fem (homens que querem fazer a cirurgia de redesignação sexual). De partida, ela aponta que o transexual típico não obtém prazer nos órgãos erradicados. Para a autora, a paixão transexualista é denunciar a ordem fálica:

Compelido pela paixão de não querer mais ser significado falo pelo discurso, o transexualista vai denunciar o erro comum de que sua natureza ficou vítima. Ele tem o falo, mas não experimenta a vocação que seria própria a esse tipo, então lhe resta denunciar a impostura que jaz no nível do discurso sexual, afinal, o critério fálico não está à altura de sua natureza ou vocação. $O$ transexualista, compelido pela sua paixão, denuncia a ordem sexual do mundo. (Caldas, 2012, p. 142)

O transexual quer aceder ao outro sexo prescindindo do gozo fálico. Nestes casos, trata-se do campo do amor, ou melhor, da demanda de ser amado. Desse modo, diz um paciente:

Porque eu tenho isso no meio das pernas... por isso eu não tenho escolha, senão o de me livrar deste tormento. Isso não me cabe. As mulheres não têm pênis. Isso me condena. Isso me deserda das chances do amor. Quem vai querer uma mulher assim? Não tenho vocação para pária! (Caldas, 2012, p. 147)

Para Caldas, o transexual quer uma prática sexual decididamente assentada na parceria com a pessoa amada. Ele quer o amor sem o falo (Caldas, 2012, p. 212). Que tipo de amor seria esse? Trata-se de uma prática a serviço do amor em que o gozo sexual é secundário. A parceria sintomática, nestes casos, aspira ao sublime. $O$ transexual-fem quer ser amado pela pessoa que ele é e não pelo que ele tem (Caldas, 2012, p. 213).

A apresentação desses pontos teóricos não tem como objetivo explorar e abranger todo o trabalho teórico dessas autoras em torno do tema. Minha proposta foi elencar alguns pontos que elas explicitam e que, inclusive, aparecem em muitos outros textos que tratam do assunto. $\mathrm{O}$ que 
me interessa discutir é o impasse em relação ao falo nesses pacientes e que consequências teóricoclínicas os analistas extraem da experiência transexual.

\section{A questão do falo ou o falo em questão?}

\subsection{O falo em questão}

Elias (2008) aponta que os casos de transexual-fem giram em torno do mal-estar em relação ao falo. Em suas elaborações teóricas sobre este conceito, ela apresenta os seguintes pontos: "o saber psicanalítico nos informa que a relação do sujeito com o falo se estabelece independentemente da relação anatômica dos sexos. Tanto a virilidade como a feminilidade dependem muito mais da função fálica do que o órgão que a representa" (Elias, 2008, p. 5). Segundo Elias, "a castração é o que permitirá a sexuação, a diferenciação entre os sexos e situará a partir daí sua eleição de objeto sexual" (Elias, 2008, p. 5). Para a autora, portanto, a função fálica não tem relação com a diferença anatômica entre os sexos. $\mathrm{E}$ o pênis não é senão o representante da função fálica.

Caldas (2012) afirma que, na solução transexual, ocorre uma sexuação fora do campo do falo. Seria uma solução no campo do amor, do amor sem sexo. Para ela, o transexual-fem precisa de um sexo recortado e configurado para o amor. Amor não erotizado, o que não os impediria de aceder ao outro sexo. Diz ela: "no trans, encontramos a exaltação da máscara. Não há outro prazer além dos prazeres da máscara. Não há nenhuma erótica decantada sob a máscara" (Caldas, 2012, p. 238). O termo máscara, no texto de Caldas, equivale à imagem, semblante, personalidade. Para o trans, trata-se de ser amado pelo que ele é - pela sua imagem - ou seja, pelo que ele parece ser. O seu sonho é que o outro, o parceiro, se apaixone pela pessoa que ele é, isto é, a sua imagem de mulher. Na falta de um parceiro, o recurso do trans-fem pode ser o de ser amado por todos, na grande cena do mundo do espetáculo.

Caldas sustenta que "a subjetividade contemporânea está totalmente convencida que a linha divisória entre os sexos pode ser franqueada" (Caldas, 2012, p. 99). Nesse sentido, segundo ela, "o binarismo homem-mulher não se sustenta mais como coordenador do erotismo. 0 órgão masculino perdeu o valor" (Caldas, 2012, p. 99). Do ponto de vista psicanalítico, ela afirma que "não há nada de biológico no funcionamento da sexualidade" (Caldas, 2012, p. 127). Ainda segundo esta autora:

Desde Freud, a experiência psicanalítica demonstra, a cada vez, que o sexual não é abordável a partir dos determinantes biológicos da diferença dos sexos. O que Freud chamou de realidade sexual do inconsciente não deve nada ao biológico, ou ao que a biologia chama de relação sexual, ou às diferenças anatômicas e celulares do organismo. (Caldas, 2012, p. 127)

A autora apresenta a ideia de que Lacan desatrelou a questão da distinção entre os sexos, nos falantes, do campo da diferença anatômica. Segundo ela, citando Lacan, "o corpo nada deve ao 
organismo e que a relação de cada um ao seu sexo depende estritamente do discurso sexual e das identificações que esse discurso promove" (Caldas, 2012, p. 132). Caldas (mai.-out. 2012) retoma a tese de que hoje verifica-se a perda do valor do pênis como órgão da diferenciação sexual e de que a significação fálica está desconectada do órgão masculino a partir da diferença feita por Lacan entre o pênis e o falo. Nesse sentido, o órgão (pênis) teria perdido o seu valor como instrumento da diferenciação entre os sexos. Desse modo, a significação fálica estaria, hoje em dia, completamente desconectada do órgão masculino.

Cossi (2011) entra na questão da relação entre o falo e o pênis, pela via de uma crítica ao primeiro ensino de Lacan. Segundo Cossi, "para Lacan, nesse momento de sua obra, o sujeito estrutura-se na matriz das relações normativas da heterossexualidade. A passagem pelo Édipo normalizaria o sujeito e faria que sexo e gênero fossem correspondentes" (Cossi, 2011, p. 90). Nesse sentido, em Lacan, diz Cossi "[...] o falo é concebido como uma referência universal a partir da qual as posições masculinas e femininas seriam dedutíveis. $\mathrm{O}$ falo simbólico seria encarado como uma substância única e só haveria dois modos de se relacionar a ele: o masculino e o feminino" (Cossi, 2011, p. 91). Para o autor:

[...] essas ideias reforçam a tese de que aquilo que promove a inteligibilidade (relativa à diferença sexual) seria 0 enquadramento às normas da heterossexualidade compulsória pautadas no falocentrismo: o sujeito só existiria à medida que entrasse no simbólico e se posicionasse de um dos lados da binaridade sexual, o que se traduziria nas duas formas possíveis de se relacionar com o falo, cujo caráter é universal e substancial. (Cossi, 2011, p. 91)

Para Cossi, a partir do momento em que Lacan passa a se dedicar ao real, surge uma abertura na psicanálise para "incluir os gêneros não inteligíveis e as novas sexualidades como possibilidades legítimas, sem relegá-las à patologia" (Cossi, 2011, p. 92). Este deslocamento se daria, segundo o autor, a partir das fórmulas da sexuação. Com elas, Lacan "[...] especifica a diferença entre o gozo masculino e feminino, algo que definitivamente não é relacionado às diferenças biológicas existentes entre homens e mulheres" (Cossi, 2011, p. 93). Nesse sentido, "[...] mesmo Lacan tendo dividido os seres humanos de uma forma sexualmente tradicional, nessa teoria (fórmulas da sexuação) há uma abertura para outras formas de sexualidade quando se postula que existe algo além do falo" (Cossi, 2011, p. 95). Haveria, portanto, um avanço na concepção lacaniana da sexualidade. O falo não é mais o único organizador das práticas de gozo. Cossi cita Dunker:

[...] derruba-se a concepção universalista da sexualidade. Por outro lado, não há falocentrismo; não porque o falo não esteja presente, mas porque ele não está mais 
no centro e não funciona como operador para pensar toda a sexualidade. Não há a sexualidade, mas as sexualidades (Dunker, 2004, p. 125 apud Cossi, 2011, p. 95).

Aliás, na orelha deste livro de Cossi, Dunker afirma que o livro "representa uma libertação diante das péssimas ideias que os psicanalistas tiveram a respeito desse tema (o transexual) ao longo do tempo" (Cossi, 2011, s.p.).

Porchat (2012, out.-2013, mar.) alinha-se a Bento (2006, apud Porchat, 2012, out. a 2013, mar.) e a Butler (2004 apud Porchat, 2012, out. a 2013, mar.) na perspectiva de que:

Muitos indivíduos que buscam a cirurgia o fazem pela necessidade de conformação ao discurso predominante: ter de pertencer necessariamente a um sexo ou outro, isto é, como se tivessem que se submeter à ideia de que a cirurgia garantiria ou seria uma espécie de última palavra sobre o gênero - um homem ou uma mulher de verdade. Para isso, precisam se acreditar ou se fazer doentes. (Porchat, 2012, out. a 2013, mar., p. 199)

A partir de Butler, Porchat afirma que "o imperativo heterossexual cria uma esfera de identificações permitidas e, simultaneamente, uma esfera de abjeto. $O$ abjeto se traduz por aquilo que é jogado fora, excluído, produzindo um campo de ação a partir do qual se estabelece a diferença (Porchat, out. 2012-mar. 2013, p. 199). Porchat, seguindo Butler, critica o limite da psicanálise, a qual trabalharia com a concepção binária de gênero. Para a primeira:

[...] o gênero é sempre pensado em sendo dois, pois, afinal, a maioria (dos psicanalistas) considera o sexo anatômico como referência para o gênero. Pode-se admitir uma discordância entre sexo anatômico e gênero, mas, sendo dois sexos anatômicos, acredita-se que serão dois os gêneros (masculino e feminino). (Porchat, 2012, out. a 2013, mar., p. 200)

Para Porchat, "trabalhar com uma noção de gênero binária empobrece a capacidade de lidar com o outro ser humano", correndo o risco de "apagamento da singularidade, na medida em que se deixa de escutar o específico de cada pessoa trans" (Porchat, out. 2012-mar. 2013, p. 200). Esse parece, para a autora, ser um limite da psicanálise.

Rocha Miranda (jun. 2015) divide em três as propostas na teoria psicanalítica da diferença entre os sexos:

A primeira proposta é de Freud, quando marca a diferença entre o ter e não ter castrado/não castrado; a segunda é a diferença entre o ter e o ser, postulada por 
Lacan nos anos 1958/1960; e a terceira é a diferença que Lacan introduz com a lógica de um gozo todo e do não todo fálico. Se a realidade do inconsciente é a realidade sexual, nem toda a realidade sexual passa pelo inconsciente. [...] há um real da sexualidade que não passa pelo simbólico... escapando tanto à questão do gênero como do sexo, mas que, no entanto, é marcado pelo gozo no real do corpo/carne e independe da forma física e determina uma forma de gozo (Rocha Miranda, 2015, jun., p. 57).

A consequência dessa elaboração para a autora é que "se há partilha dos sexos e o saber de que se trata no inconsciente é o não saber sobre o sexo, não há saber sobre essa partilha, há semblante" (Rocha Miranda, 2015, p. 58). Nesse sentido, "masculino e feminino são apenas semblantes, máscaras construídas, roupas, maquiagem ou ainda temperamento afirmativo que este sujeito supõe ao masculino. Sentir-se homem ou mulher é uma questão de, através da cristalização de identificações, encontrar uma identidade" (Rocha Miranda, 2015, jun., p. 59). Esta autora toma como exemplo Portugal, país onde basta que o sujeito se declare homem ou mulher e viva como tal para ter o registro civil adequado ao seu parecer ser (Rocha Miranda, 2015, jun., p. 59). Se estamos no campo do parecer, o que é viver como tal?

Ceccarelli (1997), num artigo em que aborda a noção de diferença sexual na psicanálise, aponta que, a partir de Lacan, se evidencia que a "inscrição do sujeito na função fálica é feita sem levar em consideração a diferença anatômica entre os sexos" (Ceccarelli, 1999, p. 157). Além disso, aponta que:

Feminilidade e masculinidade passam a ser duas representações do falus, fazendo com que a identidade do sujeito seja da ordem do significante. É a partir da inscrição na função fálica que o sujeito se posicionará no simbólico como homem ou mulher. Na grande maioria dos casos essa inscrição coincide com a anatomia, mas nem sempre (Ceccarelli, 1999, p. 158).

Por que será que na grande maioria dos casos essa inscrição coincide com a anatomia?, eu me pergunto. Proponho a hipótese de que, ao sabor do gosto da nossa época, há um mal-estar em relação ao falo, por parte dos pacientes (nos seus relatos) e dos psicanalistas (nos seus textos). É nessa discussão que pretendo avançar a partir daqui. Inicialmente, penso que podemos extrair, dos artigos psicanalíticos que foram trabalhados por mim, a existência de uma teoria da sexualidade implícita, não formalizada, cujos principais pontos seriam:

- A relação dos sujeitos ao falo independe da relação anatômica entre os sexos;

- A significação fálica está desconectada do órgão masculino a partir da diferença feita por Lacan entre o pênis e o falo; 
- Do ponto de vista psicanalítico, não há nada de biológico no funcionamento da sexualidade;

- A diferença sexual nada tem a ver com o biológico ou com a diferença anatômica;

- O binarismo homem - mulher não se sustenta mais como coordenador do erotismo. $O$ órgão masculino perdeu o valor;

- Lacan desatrelou a questão da distinção dos sexos nos falantes do campo da diferença anatômica;

- A norma heterossexual constrange a liberdade sexual e é responsável pelo sofrimento, pelo mal-estar dos sujeitos;

- O sexo, no falante, depende estritamente do discurso sexual;

- O sexual diz respeito a uma satisfação bizarra, estrangeira, irreconhecível que excede o sujeito. Lacan denominou essa experiência como gozo;

- O amor fálico - amor da norma fálica - é um tipo de amor de retidão, que não aquiesce a outras formas de gozar, formas mais livres, abruptas, anônimas, a não ser no cenário das fantasias.

O que sustenta os enunciados destes psicanalistas é o argumento de que, no campo do sexual, há uma disjunção entre falo e pênis. Há uma ideia de que a psicanálise, sobretudo a lacaniana, revelaria que a diferença sexual não tem relação com a diferença anatômica, na medida em que a organização da sexualidade humana é presidida pela linguagem. Por outro lado, esses trabalhos apontam as mudanças na cultura em relação ao campo do sexual, destacando que o órgão (pênis) perdeu o seu valor como instrumento da diferenciação entre os sexos e que, hoje, portanto, a significação fálica está desconectada do órgão masculino. Curiosamente, parece que a psicanálise e o sintomas sexuais que se apresentam na cultura atual estão de acordo. Digo curiosamente porque, para Freud e também para Lacan, a psicanálise funcionaria como um dispositivo que interrogaria os sintomas (as ficções) de sua época, buscando extrair o real (estrutural) que está em jogo. Isso mudou? Voltaremos a abordar esse ponto mais adiante.

Cabe esclarecer que três autores franceses - Morel (2012), Millot (1992) e Safouan (1979) -, que pesquisam sobre o sintoma transexual, não trabalham com a orientação que descrevi acima. Aliás, são autores amplamente citados em todos os artigos brasileiros sobre o sintoma transexual. A abordagem desses três autores sobre o conceito de falo é clássica, girando em torno da relação falopênis no campo da diferença sexual a partir dos operadores do complexo de Édipo e do complexo de castração. Com esse aparato conceitual, os três enfatizam a necessidade de não se abrir mão do diagnóstico psicanalítico nos casos de transexualismo e pretendem contribuir para o avanço da teoria sobre a relação entre o sintoma transexual e a psicose. Apoiada em Freud e em Lacan e nas contribuições desses autores, farei um breve estudo sobre o conceito de falo e da função fálica que preside as fórmulas da sexuação. $O$ objetivo é tentar circunscrever o que é o sexual para a psicanálise. 


\section{2 - A questão do falo:}

Parto das seguintes afirmativas:

- O falo não é o pênis

- O falo não é sem o pênis.

No Seminário 4, a partir do texto freudiano "O fetichismo", de 1927, Lacan define o falo como "o pênis que a mulher não tem" (Lacan, 1956-1957/1995, p. 154). Lacan comenta que Freud, de saída, afirma que o fetiche é símbolo de alguma coisa e que esta alguma coisa é o pênis. Entretanto, segundo Freud, este não é um pênis qualquer. Esta precisão, segundo Lacan, parece ter sido "pouco explorada em seu fundo estrutural" (Lacan, 1956-1957/1995, p. 154). O pênis de que se trata "não é o pênis real, é o pênis na medida em que a mulher o tem - isto é, na medida em que ela não o tem" (Lacan, 1956-1957/1995, p. 154). Portanto, não se trata em absoluto de "um falo real na medida em que, como real, ele exista ou não exista, trata-se de um falo simbólico, na medida em que de sua natureza apresentar-se como ausência, ausência funcionando como tal" (Lacan, 19561957/1995, p. 154). Desse modo, o falo em questão é um objeto simbólico. A função simbólica do falo se revela na medida em que "ele (o falo) está ali ou não está ali, e unicamente na medida em que ele não está ou não está ali, é que se instaura a diferenciação simbólica entre os sexos" (Lacan, 1956-1957/1995, p. 155). Simbolicamente, a mulher não tem o falo. Mas não ter o falo é "dele participar a título de ausência, logo, é tê-lo de alguma forma. $O$ falo está sempre para além de toda relação entre homem e mulher" (Lacan, 1956-1957/1995, p. 155). Lebrun resume da seguinte forma a relação entre o suporte corporal (o pênis) e o símbolo (o falo):

A diferença dos sexos é, no nível do desejo, o que evoca a falta de onde se constitui o sujeito. Com efeito, uma vez tomado nas coerções da língua, o sujeito não pode mais encontrar a presença plena, da mesma maneira que o objeto inteiramente satisfatório lhe faz, definitivamente, falta. (Lebrun, 2010, p. 178)

O ponto fundamental vem a seguir:

[...] essa coerção simbólica da língua é desconhecida da criança, e é preciso que esta se confronte com ela, para poder, em seguida, apropriar-se dela. É aí que a ausência do pênis em uma mulher vem, no momento oportuno, para perfurar o que não pode se apresentar na imagem senão como uma presença plena. $O$ encontro com a ausência na presença se faz, pois, primeiro por meio da imagem da diferença dos sexos. (Lebrun, 2010, p. 178)

O essencial é "[...] que a presença do pênis, que não pode se apreender fora de sua possível ausência - a anatomia de uma mulher está aí para indicá-lo - seja indicadora desse traço da língua, 
a saber, que a palavra não pode ser considerada sem o vazio que a faz existir. É, aliás, o valor do falo" (Lebrun, 2010, p. 178). O ponto crucial, a meu ver, do ponto de vista psicanalítico, é que o simbólico só se transmite encarnado. São necessários um corpo como suporte e um desejo que não seja anônimo. Voltarei a esse ponto mais tarde.

Tomo a indicação de Miller (nov. 2008-abr. 2009) sobre o Seminário 4, de Lacan. Ele afirma que todo o seminário gira em torno da sexualidade feminina e de seus efeitos sobre os filhos, na medida em que o desejo da mãe se ordena pela problemática da diferença dos sexos. O fato da mãe ser desejante, significa que há nela uma falta. Isso que lhe falta - o falo - produz a inscrição de uma perda, da castração, resultado da simbolização do Nome-do-Pai. O filho vem ocupar o lugar do que falta à mulher na equivalência simbólica, apontada por Freud, entre o falo e o filho.

O Nome-do-Pai (o Édipo) é o operador que extrai a criança do lugar do objeto que falta à mãe: o falo. Primeiro momento da lógica fálica que abre para a criança o campo do desejo, sob um fundo de ausência, de perda: não sou tudo para minha mãe. O falo como símbolo diz respeito à inscrição da castração. O complexo de Édipo possibilita que a criança interrogue a diferença anatômica entre os sexos sob a presidência da função fálica. Daí decorrem as consequências psíquicas da diferença anatômica entre os sexos. Ou seja, a subjetivação da diferença sexual - ter ou não ter o pênis - interpretada a partir da lógica fálica.

Essa operação simbólico-imaginária, sob a égide do falo, é o tratamento que o inconsciente dá ao real do sexo, que Lacan escreve com o aforisma "não há relação sexual". Isso significa dizer que é impossível escrever uma lei universal da atração entre os sexos nos seres humanos (Morel, 2012). Como consequência, para os falantes, o sexo só pode ser abordado a partir do inconsciente, ou seja, "o saber sobre o sexo é o saber inconsciente" (Morel, 2012, p. 27). No registro do inconsciente, só há a inscrição do falo, isto é, o sexual é estruturado pela função da castração. Nesse sentido, a diferença sexual não é binária. No registro imaginário, aparece como binária (homemmulher) e é entendida como uma oposição: dois lugares que se organizam por qualidades contrárias e que se complementam.

No registro simbólico, a diferença sexual, orientada pelo falo, produz uma oposição significante estrutural: entre o idêntico e o diferente (Morel, 2012, p. 79), ou entre o um e o vazio. Podemos dizer que a simbolização da desigualdade entre os sexos sustenta o traço estrutural que possibilita o laço social: a existência da alteridade como irredutível, impossível de se dissolver na igualdade. Morel (2012) aponta que, no último ensino de Lacan, o Outro é o Outro sexo. E o Outro sexo é o que resiste à identificação. Portanto, não se pode identificar o Outro, reduzi-lo ao idêntico a si próprio, no campo do narcisismo. Já no Seminário 3, Lacan (1955-1956/2008) introduz essa alteridade - o impossível de saber ou de ultrapassar - na relação entre os sexos: o Outro sexo - o feminino - é absolutamente Outro. Não pode ser definido, não pode ser absorvido na oposição imaginária homem - mulher. 
A não relação sexual significa, portanto, que, de um lado, se pode falar do homem como universal, identificando - o ao Um (todos são castrados). Por outro lado, há uma ausência, uma alteridade que não é identificável coletivamente com um significante. É o que expressa o aforisma lacaniano: "A mulher não existe" (Morel, 2012, p. 83). Desse modo, no centro da relação do sujeito ao seu sexo está a inexistência da relação sexual e, portanto, a relação necessária ao falo que simboliza a perda de gozo, estrutural, para que o sujeito advenha no campo do desejo em busca do objeto que Ihe falta. Advento do sexual. O desejo é sexual. Para Morel (2010), os dois sexos se escrevem unicamente com a função fálica, que é a função da castração. Sem a função fálica, não há como orientar-se na sexuação. "Ou melhor, há, porém ao preço da uma invenção perpétua como na psicose" (Morel, 2010, p. 57).

\section{3 - As fórmulas da sexuação:}

E o que é a função fálica? Esta não se reduz à relação binária (imaginária) homem - mulher. Vamos trabalhar com Morel (2010) para elucidar essa noção que, várias vezes, é pensada como dissociada do conceito de falo.

As fórmulas da sexuação se organizam em torno de uma função - a função fálica. O termo função diz respeito ao campo da lógica matemática, a lógica proposicional. Esta se organiza em torno de dois campos: a função, que é o elemento constante que representa o conjunto das relações e o argumento, que é o elemento variável (vazio). Assim:

$$
\begin{gathered}
\Phi(A)-\Phi \text { é a função (falo) } \\
\text { A é o argumento }
\end{gathered}
$$

Lacan, ao utilizar essas ferramentas lógicas, visa circunscrever o lugar do sujeito (argumento) com relação ao falo (função da castração). As fórmulas da sexuação permitem abordar o real como impossível, isto é, escrever o real - não há relação sexual - por meio de uma função a função fálica - em que o gozo se articula à castração. Como dissemos, a função fálica é o elemento constante. Essa constância deve ser entendida, primeiramente, como universalidade. Ou seja, tratase de uma mesma função para todos, independentemente do sujeito. Não é uma escolha dele.

O sujeito se inscreve nela graças ao desejo da mãe. Como apontamos, esta deseja o falo e o sujeito se vê na necessidade de situar-se em função desse desejo (Morel, 2012, p. 119). Sendo assim, todos os sujeitos, necessariamente, estão inscritos na função fálica. Esta, portanto, sustentase na sexualidade feminina. Tornar-se mãe é querer um filho, equivalente simbólico do falo, como nos ensinou Freud. A definição do conceito de falo extrai-se no campo da sexuação feminina: o falo é o pênis que a mãe não tem. Como significante, ele é o índice de uma perda, da castração. Assim, o falo não é o pênis, também não é o representante do pênis. A função do falo diz respeito à 
experiência inaugural do sujeito: o corpo de um bebê, investido pelo desejo particular da mãe, surge como um corpo que goza e que fala. Daí advém um sujeito.

\subsection{1 - Os três tempos da sexuação:}

A sexuação é o processo a que todo sujeito é convocado a partir da sua relação necessária ao falo. Seguindo Freud, Morel (2012) define sexuação como a tensão entre a diferença anatômica e as suas consequências psíquicas. As consequências psíquicas dizem respeito ao campo do discurso sexual. Morel enfatiza que a sexuação não se resume ao gênero, definido por ela como um sistema de identificações imaginárias e significantes. Para ela, a sexuação inclui o real somente captado no discurso analítico. Vou me servir da ferramenta de Morel que estabelece três tempos para a sexuação. A meu ver, esse instrumento permite localizar, didaticamente, o processo de sexuação.

Morel indica um primeiro tempo em que a anatomia se impõe ao sujeito. A frase é enigmática e a autora não a explica. Interpreto essa frase na direção do que Lacan enuncia, no Seminário 19 : "de que o sexo é real, não há a menor dúvida. E a sua própria estrutura é o dual, o número dois. 0 que quer que pensemos, existem apenas dois: homens e mulheres" (Lacan, 1971-1972/2012, p. 149). Lacan enfatiza que não está falando dos órgãos sexuais, mas dos gametas. A meu ver, a anatomia se impõe na medida em que esta é o suporte no corpo desse real (os gametas) que é preciso dar conta. Ainda neste seminário, Lacan é mais enfático: " o que Freud introduziu, e há quem imagine que desconheço isso, porque falo de significantes, foi o retorno a esse fundamento que está no corpo..." (Lacan, 1971-1972/2012, p. 218). No nível do discurso, há o gozo, a verdade, o semblante e o mais-de-gozar. Diz Lacan: "É aí que isso gira. E há suporte, o que acontece no nível do corpo - de onde surge todo o sentido - mas não constituído, como que servindo de base [...] portanto, o ground está aí. Trata-se, com efeito do corpo, com seus sentidos radicais, sobre os quais não há influência alguma" (Lacan, 1971-1972/2012, p. 219). Será que é possível pensar a anatomia como um sentido radical do corpo? E que, portanto, se impõe como uma exigência de trabalho ao campo do discurso?

Penso que Lacan articula algo em torno dessa relação entre o corpo e o discurso ainda no Seminário 19. Ele parte da afirmação de que não há relação sexual, isto é, de que o sexo não define relação alguma no ser falante. Diz ele: "Não é que eu negue a diferença que existe, desde a mais tenra idade, entre o que chamamos de uma menina e de um menino. É inclusive daí que parto. Captem, desde já, que quando parto daí vocês não sabem do que estou falando" (Lacan, 19711972/2012, p. 13). Essa afirmativa se esclarece adiante: "Essa diferença que se impõe como inata é, com efeito, muito natural. Corresponde ao que há de real no fato de que, na espécie que se autodenomina homo sapiens, os sexos parecem dividir-se em dois números mais ou menos iguais de indivíduos. Esses indivíduos se distinguem, é certo" (Lacan, 1971-1972/2012, p. 15).

O que Lacan pretende acrescentar é que não são eles que se distinguem, mas sim "nós os distinguimos" (Lacan, 2012, p. 16). Considero que Lacan propõe a articulação necessária entre um 
sentido radical do corpo (a anatomia) e o campo do discurso para que a sexuação se constitua. É o que Morel assinala quando afirma que "[...] é no segundo tempo, o do discurso sexual, quando o discurso dos outros transmite (ao sujeito) a interpretação do seu sexo" (Lacan, 1971-1972/2012, p. 14). Trata-se da interpretação do real (sentido radical do corpo, enigmático) por critérios fálicos. Isso possibilita a articulação entre corpo (sexuado) e semblante (gênero). O segundo tempo lógico já implica uma eleição por parte do sujeito: inscrever-se ou não sob o amo do discurso sexual, o falo. Como assinala Morel, a estrutura psicótica diz respeito aos sujeitos que rejeitam essa inscrição e a sua sexuação, portanto, não se dá sob a primazia da função fálica (Lacan, 1971-1972/2012, p. 141). O terceiro tempo diz respeito ao campo da neurose, isto é, aos sujeitos que aceitaram previamente a inscrição na função fálica (Morel, 2012, p. 140), na operação do Édipo. Retomando Lacan, com as fórmulas da sexuação, para Morel, a experiência clínica mostra que há duas inscrições diferentes (homem e mulher) na função fálica e que estas correspondem a duas posições com respeito ao gozo.

Numa análise, esse ponto real (gozo) em jogo é elucidado depois de um processo de decantação, de dedução e de demonstração que possibilita recortar qual é a posição sexuada de um sujeito. Segundo Morel, é impossível fazer um deciframento à margem da prática psicanalítica. Ao incluir o real, as conclusões a que um psicanalista chega em termos da sexuação muitas vezes chocam e vão na contramão da tendência vigente na cultura contemporânea de que o sexo é uma questão de escolha, de opção e de que se é livre para fazê-lo. A psicanálise sabe, a partir da experiência clínica, a força de um imperativo de gozo que se impõe ao sujeito, que aí, não há nada livre. No campo do gozo - isso goza - e o sujeito padece desse imperativo, desse forçamento. A meu ver, o desmentido sobre o sexo na cultura incide sobre esse ponto. Como dissemos, nas fórmulas da sexuação só há uma função: a função fálica. Lacan propõe os quantificadores dessa função e, a partir deles, propõe as fórmulas da sexuação.

Quantificadores:

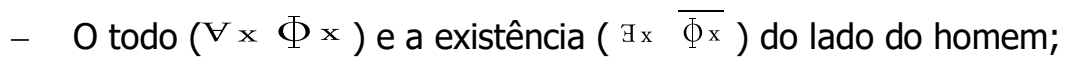

- O não todo ( $\overline{V_{x}} \Phi x$ ) e a não existência $\left(\overline{G_{x}} \overline{\Phi_{x}}\right.$ ) do lado da mulher.

Fórmulas da sexuação:

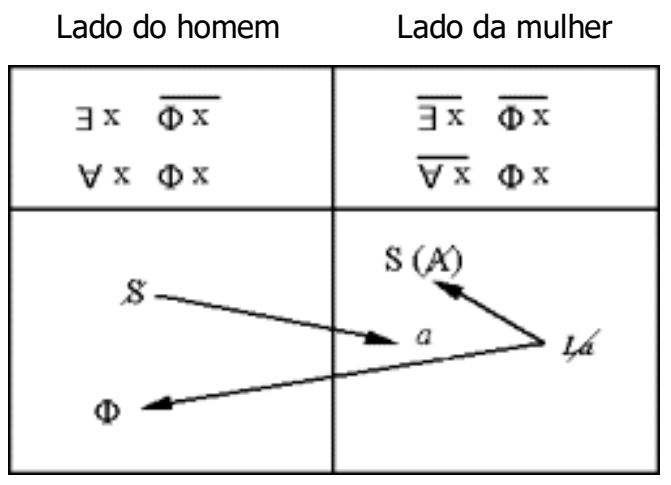

Fórmulas da sexuação (Lacan, 1972-1973/2008) 
Segundo Morel, para sexuar-se, " o sujeito não se inscreve diretamente nessa função, como se fosse uma questão de dizer sou fálico ou não sou fálico, que valeria para ambos os sexos" (Morel, 2012, p. 143). A autora enfatiza que o sujeito se inscreve como modo de gozo do falo: "na relação com o outro sexo, estou inscrito por intermédio da função fálica, portanto, sou homem, ou, na relação com o outro sexo, estou não toda inscrita na função fálica, portanto, sou uma mulher". (Morel, 2012, p. 163)

O trabalho de Lacan, com as fórmulas da sexuação, tenta definir os dois sexos como dois modos distintos do uso do falo no laço com o outro sexo, laço que sempre fracassa, de diversas formas, ao tentar estabelecer uma relação (Morel, 2012, p. 145). Nesse sentido, há sempre o outro sexo. Ou seja, no campo do sexual, não há completude, igualdade ou complementaridade. Em qualquer sujeito, em relação ao sexo, só há sintoma, índice da não relação sexual (o real) e condição para que se constitua uma relação possível.

\subsection{2 - O sintoma transexual}

Dizer que o sintoma do sujeito diz respeito ao campo do sexual é o princípio fundamental da teoria freudiana, desde os primeiros estudos de Freud sobre a histeria. A noção de sintoma articula, necessariamente, sexualidade e inconsciente. $O$ inconsciente é sexual. Cabe ao psicanalista elucidar, caso a caso, a estrutura do sintoma de cada sujeito. Portanto, para um psicanalista, não se trata de abordar o transexual, mas o sintoma transexual e verificar qual a estrutura subjetiva inconsciente que subjaz e sustenta esse sintoma.

O sintoma transexual é um efeito do processo de sexuação que, como dissemos, implica uma relação necessária ao falo. Qual é, portanto, a relação do sintoma transexual com o falo? Fenomenologicamente, o sintoma transexual se faz presente em sujeitos diagnosticados como portadores de transexualismo primário pela psiquiatria. É a amostra que nos interessa. Estes sujeitos possuem as seguintes características:

- São sujeitos que se apresentam como normais, não contradizem a ordem do mundo e, frequentemente, possuem ideais bastante convencionais;

- Simplesmente, afirmam que não nasceram com o sexo adequado, que são objeto de um erro da natureza e que sempre souberam disso (desde a infância).

A hipótese de Morel é que, nestes casos, trata-se de uma rejeição aguda do discurso sexual, que é a união dos tempos um e dois da sexuação, "precisamente no ponto em que esse discurso interpreta o órgão de modo exclusivamente fálico" (Morel, 2012, p. 186). O problema está na união entre o simbólico e o real. Essa disjunção entre o real e o simbólico permite compreender a ideia delirante que denuncia a ordem do mundo (da natureza, no caso) que não é conforme à verdade do ser de exceção que ele encarna. Entretanto, para Morel, a loucura do transexual consiste em querer forçar o real mediante a cirurgia: a loucura é querer corrigir a anatomia. Isso implica admitir que essa parte do corpo (região genital) não foi simbolizada, sob os critérios fálicos. Assim, para o 
transexual, mulher, homem, pênis, vagina não são significados do significante fálico (Morel, 2012, p. 186).

Retomando Lacan, Morel afirma que o sujeito transexual rejeita não o órgão, mas o significante falo, como significante do gozo sexual (Lacan, 1971-1972/2012, apud Morel, 2012). Nesse sentido, o sujeito, quando invoca o órgão, é para eliminá-lo, evidenciando uma ausência de sentido radical e angustiante. Trata-se de um pedaço de carne que causa horror ao sujeito e precisa ser extirpada. Neste ponto, o órgão sexual se presentifica como um ataque ao seu ser feminino, solução imaginária que lhe permite uma estabilização. A expectativa da cirurgia não gira em torno de experimentar o gozo sexual do outro sexo, mas sim, porque a presença do órgão ataca, essencialmente, o seu ser, a sua identidade feminina, que se conjuga na aparência e na identidade civil e social. Para Morel, o que o transexual exige com a cirurgia é uma variante da automutilação frequente na psicose - porém disfarçada de normalidade, em nome de uma suposta liberdade de cada um dispor do seu corpo e do direito a uma reparação do erro da natureza por parte da sociedade.

\subsection{3 - O sintoma transexual e a psicose: o empuxo à mulher sob a lógica das fórmulas da sexuação}

O empuxo à mulher é o nome dado por Lacan à orientação feminina na psicose. Inicialmente, é preciso diferenciar a sexuação feminina nas fórmulas da sexuação do empuxo à mulher que se apresenta em algumas psicoses. Nas fórmulas da sexuação, o lado mulher escreve a eleição da posição feminina num sujeito não psicótico. A posição da mulher é não toda fálica. Essa posição não significa uma não relação ao falo. O não todo implica uma parte relativa ao gozo fálico, pela posição da mulher como objeto $a$ de um homem. Assim, segundo Morel, a fórmula do não todo precisa ser lida com a do pai: a função fálica não pode existir sem o Nome-do-Pai (Morel, 2012, p. 224). Freud apontou essa estrutura quando indicou que a constituição da posição feminina na mulher passa pelo pai. Do lado homem existe a exceção à função fálica ( $\Xi_{\mathrm{x}} \overline{\Phi \times}$ ), isto é, existe um que não está inscrito na castração e que funda o conjunto dos homens como um todo. Do lado mulher, temos a fórmula da inexistência que se lê: não existe exceção à função fálica $\left(\overline{{ }_{\mathrm{x}}} \overline{\Phi_{\mathrm{x}}}\right)$ que funde 0 conjunto das mulheres como um todo. Precisamente, A mulher não existe como um universal. A mulher não existe, é um real que se vincula à "não relação sexual".

O gozo, na psicose, desprovido de significação fálica, se aloja num delírio que contempla uma significação feminina. Este seria o caso dos transexuais primários que têm a conviç̧ão de serem mulheres (sem qualquer outro ponto delirante) e a exigência da operação de mudança de sexo. Para Morel, em geral, esse sujeito transexual se preocupa muito pouco com o seu órgão e com o gozo advindo deste. $O$ seu interesse se centra, exclusivamente, na sua eliminação. O seu gozo feminino é associado ao uso ou à manipulação de roupas femininas e a sua autocontemplação no espelho. Há, neste ponto, uma continuidade entre o delírio de Schreber como mulher e a psicose não desencadeada desses sujeitos. Nesses casos, para Morel, há a articulação da significação feminina 
atribuída ao gozo e à predominância do registro especular. Durante o estádio do espelho, a matriz de um eu ideal feminino se constituiria precocemente por meio de uma identificação imaginária com a mãe (Morel, 2012, p. 215). De que mulher se trata no empuxo à mulher na psicose? Morel afirma que a feminização em casos de psicose tenta fazer existir A mulher como fora da lei simbólica. Esta é a tese de Lacan quando enuncia que A mulher não existe, a não ser fora da lei (Lacan, 19711972/2012, apud Morel, 2012). Esta articulação da feminização, como fora da lei fálica, se mantém no conceito de empuxo à mulher.

As fórmulas da sexuação só valem para um sujeito que inscreve seu gozo na função fálica. Isso ocorre no caso das fórmulas do pai ( $\mathrm{Gx}_{\mathrm{x}} \overline{\Phi \mathrm{x}}$ ), do todo homem ( $\mathrm{V} \times \Phi^{\mathrm{x}}$ ) e do não todo $\left(\overline{{ }_{\mathrm{x}}} \Phi \mathrm{x}\right)$. Para Morel, a fórmula da inexistência $\left(\overline{{ }_{\mathrm{x}}} \overline{\Phi \mathrm{x}}\right.$ ) pode ser lida em relação ao empuxo à mulher na psicose (Lacan, 1973, apud Morel, 2012). Lida desse modo, a fórmula da inexistência ( $\overline{\Xi_{\mathrm{x}}} \overline{\Phi_{\mathrm{x}}}$ ) está dissociada da fórmula do não todo $\left(\overline{{ }_{\mathrm{x}}} \Phi \mathrm{x}\right.$ ), pois como dissemos, o não todo implica a inscrição da função fálica. Portanto, é preciso ler essa fórmula da seguinte forma: o pai não existe (foraclusão do Nome-do-Pai), então "A mulher existe" (empuxo à mulher). Nesse sentido, "A mulher" somente pode existir fora da Lei fálica. Temos, então, a seguinte lógica:

- Na neurose - pai (a exceção) existe, então, A mulher não existe;

- Na psicose - o pai (a exceção) não existe, então, A mulher existe.

Cabe, portanto, destacar a diferença e a dissimetria entre a orientação do gozo pelo falo e por "A mulher". Na neurose, o falo, significante universal, é uma referência do discurso materno antes que o Nome-do-Pai venha como ponto de referência para o gozo do sujeito. Não é o caso de "A mulher", que o sujeito dever construir como uma ficção. Assim, a existência de "A mulher" é uma construção erigida sobre um vazio, efeito da foraclusão do Nome-do-Pai. 0 empuxo à mulher é uma interpretação não fálica do gozo a partir do significante A mulher, portanto, constitui uma alternativa, na estrutura, ao Nome-do-Pai e à significação fálica. Cabe lembrar que "A mulher" não tem, na psicose, a mesma função que o falo tem na neurose. Segundo Morel, clinicamente, ela se apresenta ora como uma fixação a uma imagem, ora como uma aspiração delirante (Morel, 2012, p. 232). A tendência a interpretar o gozo como feminino, na psicose, implica numa regressão, com consequências devastadoras sobre o sujeito. No caso de Schreber, a necessidade de emasculação ligada à foraclusão fálica impõe a morte do sujeito: tentação suicida, cadaverização do corpo, perda do sentimento vital, caducidade da identidade viril. Em outros casos, como no transexualismo, surgem tentativas de automutilação e demandas pela cirurgia de redesignação sexual.

\section{0 desmentido na cultura: o sexo, a gente inventa?}

O longo e laborioso trabalho em torno do transexualismo me serviu para extrair o osso desse fenômeno: do ponto de vista da clínica psicanalítica, o sintoma transexual, estrito senso, é uma solução, para alguns sujeitos, no sentido da construção de uma identidade sem o apoio do Nomedo-Pai, isto é, fora da função fálica. Trata-se, portanto, de uma questão relativa ao ser do sujeito e 
não ao sexual propriamente dito. O sujeito busca manter a unidade do seu ser mesmo que seja à custa da retirada dos seus órgãos sexuais pelos quais sente desprezo, vergonha, horror.

Esse encaminhamento me permite enunciar a questão que motiva este trabalho: por que essa solução - uma entre as várias respostas possíveis aos impasses subjetivos - parece ter se deslocado para o paradigma da sexualidade na contemporaneidade? Há duas teses que sustentam esse panorama:

- A tese de que escolher o próprio sexo é um direito e isso implica em admitir que a escolha do sexo é livre;

- A de que a diferença sexual articulada à anatomia é ultrapassada. Isto é, trata-se da ideia de que a relação ao falo (norma fálica) não é estrutural e, portanto, necessária, para a organização sexual dos indivíduos.

A norma fálica é tomada por vários autores, psicanalistas inclusive, como repressiva, razão pela qual precisaria ser relativizada, deixando de ser o operador privilegiado da sexuação. A meu ver, a clínica com transexuais não autoriza a ideia de que eles são livres para escolher o próprio sexo e que, inclusive, inventam uma nova forma de sexuarem-se. Vejamos alguns depoimentos de transexuais.

1. Diz um candidato à cirurgia: "homem é homem, mulher é mulher. Não tem meio termo" (Elias, 2008, p. 8). A demanda deste sujeito era a de retificar no corpo o que estava fora da ordem heterossexual: uma alma feminina no corpo de um homem.

2. Segundo uma vinheta clínica relatada por Caldas: "[...] Porque eu tenho isso no meio das pernas... Por isso eu não tenho escolha, senão me livrar desse tormento, Isso não me cabe. As mulheres não têm pênis. Isso me condena. Quem vai querer uma mulher assim? Não tenho vocação para pária!" (Caldas, 2012, p. 147).

3. Ainda em Caldas, outro depoimento de um sujeito depois da cirurgia: "Fiquei convicto de que a aproximação mais vizinha da perfeição à qual a humanidade pode aspirar se encontra na mulher que passou o limiar da menopausa. Em todos os países, em todas as raças, estas mulheres são, no conjunto, as pessoas que mais admiro. E é em suas fileiras - eu me lisonjeio em pensar - mesmo que seja em último lugar, mesmo se apenas no flanco lateral, que eu me fiz admitir" (Caldas, 2012, p. 70). A meu ver, só um homem pode pensar a menopausa dessa forma idílica... O que está em jogo aí, aponta Caldas, é a ideia da mulher libertada do sexo, do desejo e de tudo que supõe de incompleto. A mulher na menopausa é o objeto de exaltação desse sujeito.

4. Há, ainda, o depoimento de um sujeito a Lacan: " quando estou vestido de mulher é todo o meu corpo que experimenta uma satisfação, uma alegria, de um jeito diferente. Eu me interesso por tudo quando estou vestido de mulher. Eu não posso admitir ser um homem" (Lacan, 1976 apud Caldas, 2012, p. 56). 
Segundo Lipovestky (2005 apud Caldas, 2012, p. 101), haveria uma nova moralidade em jogo que amplia o campo dos direitos do indivíduo sobre si mesmo em detrimento dos deveres, inclusive consigo próprio, como contrapartida. Estes envolvem o direito à autodeterminação subjetiva, à livre utilização dos corpos e à escolha do próprio sexo. A convenção europeia dos direitos humanos, no artigo 8, garante a qualquer pessoa o respeito à sua vida particular e familiar, o direito de cada indivíduo de amar e manter relações com os outros, tendo em vista o desenvolvimento e o aperfeiçoamento da própria personalidade. Este artigo tem sido interpretado, em várias Cortes de justiça no sentido de que a superação das barreiras do corpo que condicionam o distúrbio de gênero permitiria a reconciliação da pessoa consigo mesma (Caldas, 2012, p. 100). É importante ressaltar que essa posição desconsidera um outro princípio que é a indisponibilidade do estado pessoal (Lipovestsky, 2005 apud Caldas, 2012, p. 100). Este princípio postula que é vetado ao indivíduo, mesmo que queira, realizar atos de violência contra o seu próprio corpo, marcando o dever moral do sujeito para consigo mesmo, proibindo a mutilação voluntária. Em termos psicanalíticos, trata-se de não autorizar o sujeito a entregar o seu corpo a um gozo mortífero.

Nos trabalhos que li sobre o transexualismo, nenhum aborda a retirada do pênis, dos testículos, dos seios e/ou dos ovários como mutilação. Caldas atravessa o assunto, com a posição de que a extração do pênis não seria uma mutilação porque, hoje em dia, o pênis perdeu o seu valor, não é mais o elemento que define a sexuação humana (Caldas, 2012). Cabe perguntar: se o pênis é esse pedaço de carne insignificante, por que essas pessoas passam por cirurgias dolorosas e perigosas impelidas, justamente, por uma relação insuportável com o seu pênis? Apenas Morel (2012) aborda a questão da mutilação nestes casos, afirmando que os psicanalistas devem avaliar se é possível outra solução, outro arranjo psíquico para o sujeito que não a cirurgia.

Parece importante distinguir a experiência do transexual, que diz respeito ao campo da clínica, do discurso sobre o transexualismo tomado, por vários autores como um fenômeno da civilização contemporânea. Millot (1992) assinala que, como fenômeno de civilização, o transexual responde ao sonho da sociedade contemporânea de recuar e, até mesmo, abolir os limites que marcam a fronteira onde começa o real, isto é, o sexo e a morte. Seguindo Millot, o transexualismo revela o paradigma da civilização contemporânea: a fantasia de que não se deve nada a ninguém, nem ao próprio corpo. Sobre essa nova moral em jogo, Lipoveskty (2005 apud Caldas, 2012) aponta o direito à recomposição de si próprio para além dos ditames corporais. Cada um pode dispor de si mesmo e do seu corpo livremente. O estado pessoal e o respeito ao corpo humano já não são concebidos no sentido absoluto, isto é, não são mais sagrados.

Como dissemos, o que está em jogo é a ilusão de eliminar o real. A partir desse desmentido, opera-se progressivamente, a passagem do transexualismo do campo da psicopatologia (século XIX) ao campo dos direitos humanos (século XXI). Vejamos que operadores permitiram essa migração. Tomo aqui como referência o trabalho de Castel (2001) sobre este tema. Castel aponta que o surgimento da noção de gênero possibilita abrigar o transexualismo, via DSM-IV, sob o diagnóstico 
de um distúrbio de identidade de gênero. No campo da psiquiatria, portanto, trata-se de um transtorno de gênero. Segundo Castel, a noção de gênero consagra o triunfo, na psiquiatria, de uma concepção sociológica da identidade (Castel, 2001, p. 78). A noção de gênero na sociologia, nos Estados Unidos, pós-segunda guerra mundial, estuda os papéis funcionais dos indivíduos. O gênero, portanto, diz respeito aos papéis sexuais que se estabelecem numa cultura. Desse modo, a identidade sexual resultaria de um aprendizado do "papel de gênero". Para Castel, os trabalhos que surgem a partir deste conceito terão como resultado consagrar definitivamente a distinção entre o sexo biológico e o gênero psicossocial (Castel, 2001, p. 87). Em 1962, a nova edição do Oxford English Dictionary assinala que sexo e gênero não são equivalentes, mas que gênero acentua a definição social e cultural, por oposição à biológica. (Castel, 2001, p. 97). A disjunção entre sexo anatômico e gênero possibilita localizar o fenômeno do transexualismo no campo da psiquiatria como um transtorno de gênero.

No DSM-IV, o transexualismo é identificado como uma disforia de gênero, termo que Castel nomeia como um híbrido psiquiátrico-sociológico (Castel, 2001, p. 80). Esta designação por parte campo médico possibilita a legitimação da proposta terapêutica na direção da cirurgia de redesignação de gênero. Castel aponta que a definição de DSM não tem qualquer ambição nosográfica. Ela "replica palavra por palavra a demanda dos transexuais, transportando seu autodiagnóstico para a definição médica da síndrome e consagra, no mesmo movimento, como única escolha terapêutica, aquela que eles solicitam - hormônios e cirurgia" (Castel, 2001, p. 90). O que está em jogo, para este autor, é que a anormalidade sintomática do transexualismo passa a ser medida pela inadequação social em lugar de um critério de saúde mental.

No mesmo sentido da ideia de adequação social, no campo da medicina, vemos surgir um critério nomeado por Caldas como pragmático (Castel, 2001, p. 111). Numa entrevista com um cirurgião que trabalha com a cirurgia de redesignação de sexo, é-lhe apresentado um caso hipotético: um sujeito se considera James Dean e demanda uma cirurgia para transformar o seu rosto no rosto de James Dean. Ele seria considerado louco? O cirurgião responde que sim. Questionado se essa lógica não deveria ser aplicada ao transexual, o cirurgião argumenta: "o primeiro pedido parece bizarro porque a técnica cirúrgica para a adequação à forma facial de outrem ainda deixa a desejar" (Caldas, 2012, p. 111). Assim, conclui-se que, se a técnica cirúrgica possibilita a mudança de sexo para um sujeito, esse sintoma deixa de ser loucura. Além do avanço das técnicas cirúrgicas, o progresso no estudo dos hormônios, na endocrinologia, passou a possibilitar a alteração dos caracteres sexuais secundários.

Resumindo, a disjunção sexo-gênero, extraída do campo da sociologia e instrumentalizada pela medicina (psiquiatria, cirurgia plástica e endocrinologia) são os operadores que transportam o transexualismo para o campo da vontade - querer mudar de sexo - e do direito - direito à liberdade para escolher o seu sexo. E os psicanalistas? Que lugar ocupam nessa discussão? Como indiquei, na primeira parte deste trabalho, a disjunção sexo//gênero sustenta-se no questionamento da diferença 
sexual apoiada no conceito de falo. Os artigos que trabalhei são de psicanalistas brasileiros de orientação lacaniana. Há um consenso entre eles: o falo nada tem a ver com a anatomia (o pênis). Recupero frases paradigmáticas dessa posição nesses textos:

- A diferença sexual, do ponto de vista psicanalítico, nada tem a ver com o biológico ou com a diferença anatômica;

- A relação de cada um ao seu sexo depende estritamente do discurso sexual. O corpo nada deve ao organismo;

- Desde Freud, a experiência psicanalítica demonstra que não há nada de biológico no funcionamento da sexualidade;

- O pênis perdeu seu valor como órgão da diferenciação sexual;

- Para Freud, a sexualidade é desnaturalizada e sempre infantil. Nós nos inserimos na partilha dos sexos, como homem ou mulher e não pela anatomia. Isto é, trata-se da possibilidade do sujeito se colocar do lado da posição feminina ou masculina, independentemente da anatomia;

- Um transexual masculino, ao constituir-se como mulher, sabe mais o que é ser uma mulher do que qualquer outra mulher, demonstrando que o suposto original (ser mulher) é apenas uma construção;

- A relação do sujeito ao falo se estabelece independentemente da diferença anatômica entre os sexos;

- Evidencia-se a precariedade da solução proposta por Lacan (primeiro ensino). Tal teorização parte do pressuposto de que há uma substância intrínseca aos gêneros (o falo). É impossível assumir e realizar as identidades sexuais, cuja natureza é fantasística. Além do mais, o falo é concebido como uma referência universal a partir da qual as posições masculina e feminina seriam dedutíveis. $O$ falo simbólico é encarado como substância única e só haveria dois modos de se relacionar a ele: o modo masculino e o feminino. Por outro lado, alguns autores, psicanalistas, argumentam na direção da despatologização do transexualismo e criticam a relação entre gênero e sexo anatômico na psicanálise:

- O limite da psicanálise consiste em trabalhar exclusivamente com a noção binária de gênero. O gênero é sempre pensado em sendo dois, pois a maioria considera o sexo anatômico como referência para o gênero. Esse limite - trabalhar com a noção binária de gênero - empobrece a capacidade da psicanálise em lidar com o outro ser humano;

- As identidades trans são diagnosticadas, pela psicanálise, como doentes e, nesse sentido, fundam o campo da saúde. Este campo é habitado por indivíduos extremamente bem adaptados ao seu gênero. A patologização do gênero cria um perigoso campo ideal de sexo e de gênero;

- Abordar o transexualismo via Verleugnung, mecanismo em ação em todo o sujeito e que opera com força no social, desloca esse quadro clínico da concepção que sempre relegou tais sujeitos ao campo do distúrbio e, dentro da psicanálise lacaniana, ao diagnóstico de psicose. Tal proposta 
possibilita não mais reduzir o fenômeno transexual a generalizações precárias e, além disso, deslocálo do campo psicopatológico.

Ao fim e ao cabo, todos concordam com a disjunção entre pênis e falo. Em alguns textos, o pênis - a diferença anatômica - até já desapareceu. Fica-se com o falo sem o pênis. Em outros, o conceito de falo é colocado em questão, desconectando o falo da função fálica nas fórmulas da sexuação. Não se trata de pensar que são erros, mas de tentar elucidar o que se abandona e o que se preserva nessa teorização e com que consequências. Penso que a ideia que subjaz a toda essa teorização é que o simbólico pode ser transmitido sem corpo, sem estar encarnado. Como apontei, Lacan é preciso, no Seminário 19, quando diz que não ignora o que Freud introduziu: "o retorno ao fundamento que está no corpo e que faz com que sejam quatro os polos determinados a partir da emergência como tal do gozo, justamente como inapreensível. É isso que faz surgir os outros três [...]" (Lacan, 1971-1972/2012, p. 218). Continuando, diz ele:

O gozo, a verdade, o semblante e o mais-de-gozar. E há o suporte, o que acontece no nível do corpo - de onde surge todo o sentido - mas não constituído, como que servindo de base, de ground [...]. Trata-se, com efeito, do corpo, com seus sentidos radicais, sobre os quais não há influência alguma. (Lacan, 1971-1972/2012, p. 218)

Não seria a diferença anatômica um sentido radical do corpo, enigma, que deixa entrever o real e, portanto, convoca a uma exigência de trabalho, de simbolização? É possível simbolizar o sexo sem levar em conta que o significante escava no corpo a zona erógena? A operação fálica implica a negativização do órgão - o falo é o pênis que a mãe não tem - e possibilita a simbolização do furo, da castração, passo necessário para o advento corpo como sexuado.

O discurso para Lacan é a estrutura encarnada. O discurso não se confunde com os ditos, as significações. O discurso é o dizer (Lacan, 1971-1972/2012, p. 221). Ou seja, é o verbo encarnado. A máquina discursiva, em Lacan, mói a carne do corpo e produz efeitos no real: os sintomas como modos de gozo. A transmissão do simbólico se enraíza no corpo. É possível, portanto, dispensarmos no conceito de falo a sua necessária articulação com esse pedaço do corpo - o pênis - sob a equação de que o falo é o pênis que a mãe não tem? Por outro lado, quais as consequências, para o sujeito, do corpo desatrelado do constrangimento fálico? O sujeito está livre para gozar do seu corpo da forma que lhe aprouver? Qualquer maneira de gozar vale a pena? Livrar-se do falo, da castração, aliviar-se do real, parece ser a proposta contemporânea que subjaz ao discurso sobre o transexualismo tomado como paradigma de uma sexualidade liberada do falo.

Dufour (2005), Lebrun (2008), Coelho dos Santos (2016, set.-out.) caminham em outra orientação. Para eles, sem a transmissão da castração, o sujeito está em apuros. Quando o Outro (a tradição, a cultura, o pai) se demite ou desmente a necessidade dessa transmissão, introduz-se um processo de dessimbolização do mundo (Dufour, 2005, p. 13). Como efeito, o sujeito se vê na tarefa 
impossível de constituir-se a si mesmo. Estes autores são unânimes em afirmar o aparecimento de um modo de existir e usufruir da vida que Dufour (s.a., apud Lebrun, 2008, p. 95) define da seguinte maneira: " um sujeito suposto nada saber..." de si mesmo e que, em vez de encontrar a liberdade, reivindica, como parceiro, um Outro extremamente consistente.

Coelho dos Santos (2016, set.-out.) defende a tese de que, na sociedade contemporânea, está em jogo:

Uma inversão, uma supressão selvagem do recalque, que expõe os fantasmas préedípicos a céu aberto. Se a neurose é o negativo da perversão, ela impõe que os desejos manifestem-se como fantasmas inconscientes recalcadas. Quando é proibido proibir, não é preciso mascarar o gozo fantasmático. Podemos exibi-lo, assumi-lo, escancará-lo e até vendê-lo no mercado para satisfação de outros indivíduos. (Coelho dos Santos, 2016, set.-out., p. 568)

A autora (2015) também levanta a hipótese de que a intimidade (gozo) tornou-se uma mercadoria que se compra e se vende. Esta hipótese se coaduna com a perspectiva de Dufour que defende que o Outro contemporâneo é o Mercado e que o ser humano e o seu corpo tornaram-se mercadorias. Isso se torna possível na medida em que os objetos são aliviados de seu valor simbólico e se tornam equivalentes, trocáveis (Dufour, 2005). Em termos psicanalíticos, podemos dizer que das Ding, o objeto perdido, que sustenta o campo do desejo, perde a dimensão de sagrado, e é reduzido a um objeto qualquer (Coelho dos Santos, 2015). O efeito desse rebaixamento é o tamponamento do objeto causa do desejo - que é o furo - pela mercadoria. Esta orientação teórica sustenta a pergunta que percorre este trabalho: a ideia de um corpo aparentemente liberado do constrangimento do falo e, portanto, do recalque é um corpo livre para gozar de outras formas de sexualidade? Quais? Um sujeito suposto nada saber de si e que, portanto, recusa o inconsciente, é livre ou, como apontam os autores que indiquei acima, é facilmente capturado a se constituir como uma mercadoria, um objeto para o gozo do Outro?

A psicanálise sabe que o sexual é o campo do desencontro, da castração, da infelicidade comum como afirmou Freud. Sabe também que passar ao largo da castração não é a liberdade e a felicidade que são encontradas, mas o aprisionamento no autoerotismo, no narcisismo cujo paradigma contemporâneo são os vícios. O campo do sexual - como paradigma do laço humano em que a felicidade é sempre sintomática e, portanto, bastante limitada e contingente, se opõe à promessa de satisfação ilimitada da sociedade de consumo. Para que enfrentar o limite real do sexo e da morte se nos é prometida a felicidade traduzida em satisfação no mundo das mercadorias? Inclusive com corpos à vontade? O que nós, psicanalistas, temos a dizer a respeito do futuro dessa nova ilusão? 


\section{Referências bibliográficas}

American Psychiatric Assotiation IV (2002). Manual Diagnóstico e Estatístico de Transtornos Mentais. Porto Alegre.

Caldas, M. T. (2012, mai. a out.) Os transexuais e o sexo pra chamar de seu. Revista aSEPHallus de Orientação Lacaniana, 714$)$, 43-73. Recuperado de http://www.isepol.com/asephallus/numero_14/revista_asephallus_14.pdf.

Caldas, M. T. (2012). A pessoa que se é: as relações entre a personalidade e o corpo numa sexuação transexualista. (Tese de doutorado). Universidade Federal de Minas Gerais, Minas Gerais.

Castel, P. H. (2001). Algumas reflexões para estabelecer a cronologia do "fenômeno transexual". Revista Brasileira de História, 21(41), 77-111. Recuperado de http://www.scielo.br/scielo.php?script=sci_arttext\&pid=S0102-01882001000200005.

Ceccarelli, P. R. (1999). Diferenças sexuais...? Quantas existem? In Ceccarelli, P. R. (Org.). Diferenças sexuais (pp. 151-159). São Paulo: Escuta.

Coelho dos Santos, T. (2015, mai. a out). O olhar sem véu: transparência e obscenidade. Revista aSEPHallus de Orientação Lacaniana, 10(20), 4-15. Recuperado de http://www.isepol.com/asephallus/numero_20/pdf/o_olhar_sem_veu.pdf

Coelho dos Santos, T. (2016, set. a out.). O Outro que não existe: da verdade verídica, verdades mentirosas e desmentidos veementes. Revista Ágora, 19(3), 565-583. Rio de Janeiro: UFRJ.

Cossi, R. K. (2011). Corpo em obra: contribuições para a clínica psicanalítica do transexualismo. São Paulo: 7Versos.

Dufour, D.-R. (2005). A arte de reduzir as cabeças: sobre a nova servidão na sociedade ultraliberal. Rio de Janeiro: Companhia de Freud.

Elias, V. A. (2008). A proibição obsessiva e a demanda transexual como resposta ao mal-estar na cultura. In III Congresso Internacional de Psicopatologia Fundamental e IX Congresso Brasileiro de Psicopatologia Fundamental. Niterói.

Freud, S. (1976). Sobre a tendência universal à depreciação na esfera do amor. In J. Salomão (Trad.). Edição Standard Brasileira das Obras Psicológicas Completas de Sigmund Freud (Vol. 11, pp. 163-173). Rio de Janeiro: Imago (Trabalho original publicado em 1912).

Lacan, J. (2008). O seminário, livro 3: as psicoses. Rio de Janeiro: Zahar (Trabalho original publicado em 1955-1956).

Lacan, J. (1995). O seminário, livro 4: a relação de objeto. Rio de Janeiro: Zahar (Trabalho original publicado em 1956-1957).

Lacan, J. (2012). O seminário, livro 19: ou pior. Rio de Janeiro: Zahar (Trabalho original publicado em 1971-1972).

Lacan, J. (2008). O seminário, livro 20: mais, ainda. Rio de Janeiro: Zahar (Trabalho original publicado em 1972-1973).

Lebrun, J.-P. (2010). O mal-estar na subjetivação. Porto Alegre: CMC Ed. 
Lebrun, J.-P. (2008). A perversão comum: viver juntos sem Outro. Rio de Janeiro: Companhia de Freud.

Millot, C. (1992). Extrasexo: ensaio sobre o transexualismo. São Paulo: Escuta Ed.

Miller, J.-A. (2008, nov. a 2009, abr.). A lógica do tratamento do Pequeno Hans segundo Lacan. aSEPHallus - Revista Eletrônica do Núcleo Sephora, 5(7), 70-85. Recuperado de http://www.isepol.com/asephallus/numero 07/traducao 1.html.

Morel, G. (2012). Ambigüedades sexuales: sexuación y psicosis. Buenos Aires: Manantial.

Porchat, P. (2012, out. a 2013, mar.). Psicanálise, gênero e singularidade. Revista Faac, 2(2), 195-

202. São Paulo: UNESP.

Rocha Miranda, E. (2015, jun.). Transexualidade e sexuação: o que pode a psicanálise. Revista Trivium, (7), 52-60. Rio de Janeiro: UVA.

Safouan, M. (1979). Estudos sobre o Édipo. Rio de Janeiro: Zahar Ed.

\section{Bibliografia Complementar}

Caldas, M. T. (2012, mai. a out.). O transexualismo e suas soluções. Revista aSEPHallus de Orientação Lacaniana, 1(2), 1-13. Recuperado de: http://www.isepol.com/asephallus/numero_02/artigo_06port_edicao02.htm

Ceccarelli, P. R. (1998). Transexualismo e identidade sexuada. In Viviani, A. (Org.). Temas da clínica psicanalítica (pp. 137-147). São Paulo: Experimento.

Coelho dos Santos, T. (2013). A anatomia é um destino para os que acreditam na natureza. Apresentação do argumento do VI ENAPOL. Paris.

Cossi, R. K. (2014, jan. a jun.). Desvinculação da experiência transexual do diagnóstico psicanalítico de psicose. Revista Psicologia e saúde, 6(1), 09-17. Mato Grosso do Sul: UCDB.

Dufour, D.-R. (2010). O divino mercado. Cadernos de psicanálise, 32(23), 55-66.

Dufour, D.-R. (2015, mai. a out.). A pleonexia, o que é? Revista aSEPHallus de Orientação Lacaniana, 10(20), 24-38. Recuperado de http://www. isepol.com/asephallus/numero 20/pdf/a pleonexia.pdf.

Lebrun, J.-P. (2004). O mundo sem limite: ensaio para uma clínica psicanalítica do social. Rio de Janeiro: Companhia de Freud.

Citacão/Citation: Antunes, M. C. C. (mai. a out. 2016). A anatomia é o destino: a psicanálise e o sintoma transexual. Revista aSEPHallus de Orientação Lacaniana, 11(22), 42-67. Disponível em www.isepol.com/asephallus. doi: 10.17852/1809-709x.2019v11n22p42-67.

Editor do artigo: Tania Coelho dos Santos.

Recebido/Received: 18/09/2016/09/18/2016.

Aceito/Accepted: 24/10/2016 / 10/24/2016.

Copyright: (C) 2013 Associação Núcleo Sephora de Pesquisa sobre o moderno e o contemporâneo. Este é um artigo de livre acesso, que permite uso irrestrito, distribuição e reprodução em qualquer meio, desde que o autor e a fonte sejam citados/This is an open-access article, which permites unrestricted use, distribution, and reproduction in any medium, provided the author and source are credited. 
Revista aSEPHallus de Orientação Lacaniana Núcleo Sephora de Pesquisa sobre o Moderno e o Contemporâneo ISSN $1809-709 \mathrm{X}$

Revista aSEPHallus de Orientação Lacaniana. Rio de Janeiro, 11(22), 42-67, mai. a out. 2016.

A anatomia é o destino: a psicanálise e o sintoma transexual 